\title{
Effects of Heavy Metals with Different Concentrations on Some Biological Properties of Hyphantria cunea Drury (Lepidoptera: Arctiidae) Larvae
}

\author{
Elif Fatma TOPKARA* Oğuzhan YANAR \\ Ondokuz Mayls University, Science and Art Faculty, Biology Department, Samsun, Turkey
}

How to cite: Topkara, E.F. \& Yanar, O. (2020). Effects of Heavy Metals with Different Concentrations on Some Biological Properties of Hyphantria cunea Drury (Lepidoptera: Arctiidae) Larvae. J. Anatolian Env. and Anim. Sciences, 5(4), 685-690.

Atıf yapmak için: Topkara, E.F. \& Yanar, O. (2020). Farklı Konsantrasyonlardaki Ağır Metallerin Hyphantria cunea Drury (Lepidoptera: Arctiidae) Larvalarının Bazı Biyolojik Özelliklerine Etkileri. Anadolu Çev. ve Hay. Dergisi, 5(4), 685-690.

*Corresponding author's: Elif Fatma TOPKARA

Ondokuz Mayıs University, Science and Art

Faculty, Biology Department, Samsun,

Turkey.

$\triangle$ : topkaraelif@ hotmail.com

Mobile telephone: +90 (542) 8481580
Abstract: The aim of this study was to determine the effects of zinc (Zn), iron (Fe), nickel (Ni), copper $(\mathrm{Cu})$, and cobalt $(\mathrm{Co})$ in different amounts on the total consumption amount, pupal weight, pupal protein and lipid content, the development time of the last instar Hyphantria cunea. For this purpose, ten artificial diets were prepared using $0.788 \mathrm{mg} / \mathrm{ml}$ and $2.364 \mathrm{mg} / \mathrm{ml}$ of each metal. A total of 11 diets were made, including one control diet. Chloroform was used to determine the pupal lipid amounts. Protein analysis was performed by semi-micro Kjeldahl method with Kjeltec Auto 1030 analyzer. ANOVA-Dunnet test was used for statistical analysis. With increasing iron and copper amounts in the diet, the larval consumption amounts, pupal weights, pupal protein and pupal lipid amounts of the insect decreased, while the development time was prolonged. Consumption amounts, pupal weights, pupal protein and pupal lipid amounts of the groups containing nickel and cobalt were found to be higher than the control group. It was determined that with increasing zinc amount, consumption amounts, pupal weights, and pupal protein amounts of the larvae increased, but pupal lipid amounts decreased. In this study, it has been shown that heavy metals affect the physiological processes of $H$. cunea larvae.

Keywords: Development time, Hyphantria cunea, lipid, protein, pupal weight.

\section{Farklı Konsantrasyonlardaki Ağır Metallerin Hyphantria cunea Drury (Lepidoptera: Arctiidae) Larvalarının Bazı Biyolojik Özelliklerine Etkileri}

*Sorumlu yazarın:

Elif Fatma TOPKARA

Ondokuz Mayıs Üniversitesi, Fen Edebiyat

Fakültesi, Biyoloji Bölümü, Samsun, Türkiye.

$\triangle$ : topkaraelif@ hotmail.com

Cep telefonu : +90(542) 8481580
Öz: Bu çalışmanın amacı, farklı miktarlarda çinko (Zn), demir (Fe), nikel (Ni), bakır $(\mathrm{Cu})$ ve kobaltın (Co) son evre Hyphantria cunea'nın toplam diyet tüketim miktarı, pupa ağırlığı, pupa proteini ve lipit miktarı ve gelişme zamanı üzerindeki etkilerini araştırmaktır. Bu amaçla, her bir metalden $0.788 \mathrm{mg} / \mathrm{ml}$ and $2.364 \mathrm{mg} / \mathrm{ml}$ kullanılarak 10 diyet hazırlandı. 1'i kontrol diyeti olmak üzere toplam 11 diyet yapıldı. Pupal lipit miktarlarının belirlenmesinde kloroform kullanıldı. Protein analizi semi-mikro Kjeldahl metodu ile Kjeltec Auto 1030 analizörü ile yapıldı. İstatistik analizlerde ANOVA-Dunnet testi kullanıld. Diyetteki artan demir ve bakır miktarları ile larvaların tüketim miktarları, pupa ağırlıkları, pupa protein ve pupa lipit miktarları azalırken, gelişme süreleri uzadı. Nikel ve kobalt içeren grupların tüketim miktarlarının, pupa ağırlıklarının, pupa protein ve pupa lipit miktarlarının kontrol grubundan fazla olduğu bulundu. Artan çinko miktarı ile larvaların tüketim miktarlarının, pupa ağılıklarının, pupa protein miktarlarının arttığı fakat pupa lipit miktarlarının azaldığı belirlendi. Bu çalışmada, ağır metallerin $H$. cunea larvalarının fizyolojik süreçlerini etkilediği gösterildi.

Anahtar Kelimeler: Gelișme süresi, Hyphantria cunea, lipit, protein, pupa ağırlığı. 


\section{INTRODUCTION}

Heavy metal pollution is one of the most important causes of environmental pollution. Heavy metals enter the environment from natural (mineral decomposition, erosion, and volcanic activities) and anthropogenic sources (mining, smelting, electroplating, pesticides and fertilizers, as well as the use of biosolids in agriculture, sludge discharge, industrial discharge, atmospheric deposition, etc.) (Ali et al., 2013). Various applications, including chemical fertilizers, cause heavy metals to accumulate in the soil, and this is not only a serious threat to plants but also a potential danger to many organisms, including humans (Hejazizadeh et al., 2016). Because heavy metals cannot be broken down, they accumulate in the body tissues of living organisms (bioaccumulation) and their amounts increase as they move from low trophic levels to higher trophic levels (a phenomenon known as biomagnification) (Ali et al., 2013). Considering the food chain, this situation can reach dangerous levels for living things.

Regarding their role in biological systems, heavy metals are classified as essential and non-essential. Essential heavy metals such as $\mathrm{Fe}, \mathrm{Mn}, \mathrm{Cu}, \mathrm{Zn}$, and $\mathrm{Ni}$ are required by living organisms in very small amounts for vital physiological and biochemical functions (Cempel \& Nikel, 2006; Göhre \& Paszkowski, 2006). Non-essential metals such as $\mathrm{Cd}, \mathrm{Pb}, \mathrm{As}, \mathrm{Hg}$, and $\mathrm{Cr}$ are metals that are not needed by living organisms for any physiological and biochemical functions (Dabonne et al., 2010; SánchezChardi et al., 2009). Many heavy metals are toxic even at very low amounts and can cause serious problems (Arora et al., 2008; Kara, 2005). The harmful effects of heavy metals have been demonstrated in studies with various animals (Brasso \& Cristol, 2008; Pedersen \& Saether, 1999; Witeska et al., 2014).

The effects of metals on insects have been shown in various studies. For example, the longevity and fecundity of adult Chromatomyia milii Kaltenbach (Diptera: Agromyzidae) and the survival of the offspring decreased with increased exposure to cadmium (Scheier et al., 2006). It was determined that crickets and locusts that consumed the leaves of Stanleya pinnata and Brassica juncea with high selenium died (Freeman et al., 2007). Görür (2010) found that cabbage and radish plants contaminated with zinc or cadmium had detrimental effects on the growth of aphids. It was determined that the survival of Heliothis virescens Fabricius (Lepidoptera: Noctuidae) decreased with an increase in zinc and cadmium amounts (Kazemi-Dinan et al., 2014).

The fall webworm, Hyphantria cunea Drury (Lepidoptera: Arctiidae), is a devastating invasive insect commonly found in North America, its region of origin (Gomi, 2007). It causes unprecedented damage and economic losses due to its excessive fecundity and wide host range, including forest and shade trees and even crops (Zhang et al., 2016). These insects can cause serious crop losses each year in Turkey.

It is essential to know the biology of the species in the fight against pest species. There are studies on the effects of various factors on the protein, lipid, and carbohydrate content of insects (Büyükgüzel \& Kalender, 2008; Sharma et al., 2011). In our study, we aimed to determine how five heavy metals ( $\mathrm{Fe}, \mathrm{Zn}, \mathrm{Cu}, \mathrm{Ni}$, and $\mathrm{Co}$ ) in different amounts affect the consumption amounts, pupal weights, pupal protein and pupal lipid amounts, and development time of $H$. cunea larvae.

\section{MATERIAL and METHODS}

Hyphantria cunea larvae were collected in Turkey's Samsun Province Çarşamba District on the field studies. The artificial diet developed by Yamamoto (1969) was used as a control diet to feed the larvae. The content of Yamamoto's artificial diet was wheat germ, casein as the protein, saccharose as the carbohydrate, torula yeast, vitamin mixture, salt mixture, cholesterol, sorbic acid, methyl paraben, linseed oil, agar, and water. Different diets were prepared by adding different amounts of $\mathrm{Fe}, \mathrm{Zn}, \mathrm{Cu}$, $\mathrm{Ni}$, and Co into this diet. For this, heavy metals prepared as $0.788 \mathrm{mg} / \mathrm{ml}$ and $2.364 \mathrm{mg} / \mathrm{ml}$ were added to the diets. In total, 11 diets were prepared, one of which was the control diet (Table 1).

Table 1. Diet types and diet contents.

\begin{tabular}{lc}
\hline Diet types & Diet contents \\
\hline $\mathrm{A}$ & Control Diet $(\mathrm{CD})$ \\
$\mathrm{B}$ & $0.788 \mathrm{mg} / \mathrm{ml} \mathrm{Fe}$ \\
$\mathrm{C}$ & $2.364 \mathrm{mg} / \mathrm{ml} \mathrm{Fe}$ \\
$\mathrm{D}$ & $0.788 \mathrm{mg} / \mathrm{ml} \mathrm{Zn}$ \\
$\mathrm{E}$ & $2.364 \mathrm{mg} / \mathrm{ml} \mathrm{Zn}$ \\
$\mathrm{F}$ & $0.788 \mathrm{mg} / \mathrm{ml} \mathrm{Cu}$ \\
$\mathrm{G}$ & $2.364 \mathrm{mg} / \mathrm{ml} \mathrm{Cu}$ \\
$\mathrm{H}$ & $0.788 \mathrm{mg} / \mathrm{ml} \mathrm{Ni}$ \\
$\mathrm{J}$ & $2.364 \mathrm{mg} / \mathrm{ml} \mathrm{Ni}$ \\
$\mathrm{K}$ & $0.788 \mathrm{mg} / \mathrm{ml} \mathrm{Co}$ \\
$\mathrm{L}$ & $2.364 \mathrm{mg} / \mathrm{ml} \mathrm{Co}$ \\
\hline
\end{tabular}

Thirty last instar larvae were put into plastic containers containing artificial diets, and the feeding experiment was started every other day. Every other day, the new diet was weighed on a 0.001 sensitive scale and given to the larvae, and the remaining nutrients were weighed after drying in the incubator. This process was continued until the larvae pupated.

Pupae were placed in an incubator set at $45^{\circ} \mathrm{C}$ to be dried and kept in the incubator until they reached a constant weight. Dried pupae were taken from the 
incubator and placed in tubes to determine the lipid amount. It was kept in pure chloroform for 24 hours on a rotating shaker, and this process was repeated 3 times (Simpson \& Raubenheimer, 2001). Thus, lipid content was removed from pupae. Then, the pupae were taken into the incubator again and dried until they reached a constant weight. The dried pupae were weighed, and their lipid-free weight was noted. Nitrogen determination of lipid-free $H$. cunea pupae was made by semi-micro Kjeldahl method with Kjeltec Auto 1030 analyzer (Tecator, Sweden). The $\%$ nitrogen amounts found as a result of this process were multiplied by the constant of 6.25 , and the $\%$ protein amounts were found (Oonincx et al., 2015).

In the study, whether the total diet consumption amounts, pupal weights, pupal lipid and pupal protein amounts, and development times of $H$. cunea larvae were statistically different from each other was determined by ANOVA test, and Dunnet test was used. SPSS 21.0 software was used for statistical analysis.

\section{RESULTS and DISCUSSION}

Among all the groups, the lowest consumption was in the larvae fed with the diet containing the highest amount of copper ( $\mathrm{G}$ diet; Mean=277.0 $\pm 0.4 ; \mathrm{F}=6801.7$;
$\mathrm{P}<0.001)$. Consumption amounts decreased with the increase in iron and copper amounts added to the diet, and it was found that the consumption amounts of these groups were lower than the control group. These results we found in our study coincide with Vesk and Reichman's (2009) study that metals can deter invertebrate insects. Deterrence causes a decrease in the consumption amount of the insect, and this situation may negatively affect the development stages of the insects. It was found that the consumption amounts of all groups containing nickel and cobalt were higher than the control group. Gonçalves et al., (2007), in a study with Tribolium castaneum Herbst (Coleoptera: Tenebrionidae), found that as the Ni amount increased, the larvae were significantly less fed and rejected the diet discs with the highest Ni amount, which is the opposite of the result we found in our study (Table 2).

In our study, it was noted that pupal weights decreased with the increase of iron and copper amounts in the diet. Consumption amounts were also low in these groups. In this case, it can be concluded that the low consumption amount negatively affects pupal weight. Similar results were found in other studies examining the effects of metals on pupal weights.

Table 2. Total consumption amount, pupal weight, pupal protein and lipid amount, and development time of Hyphantria cunea larvae according to their diet types.

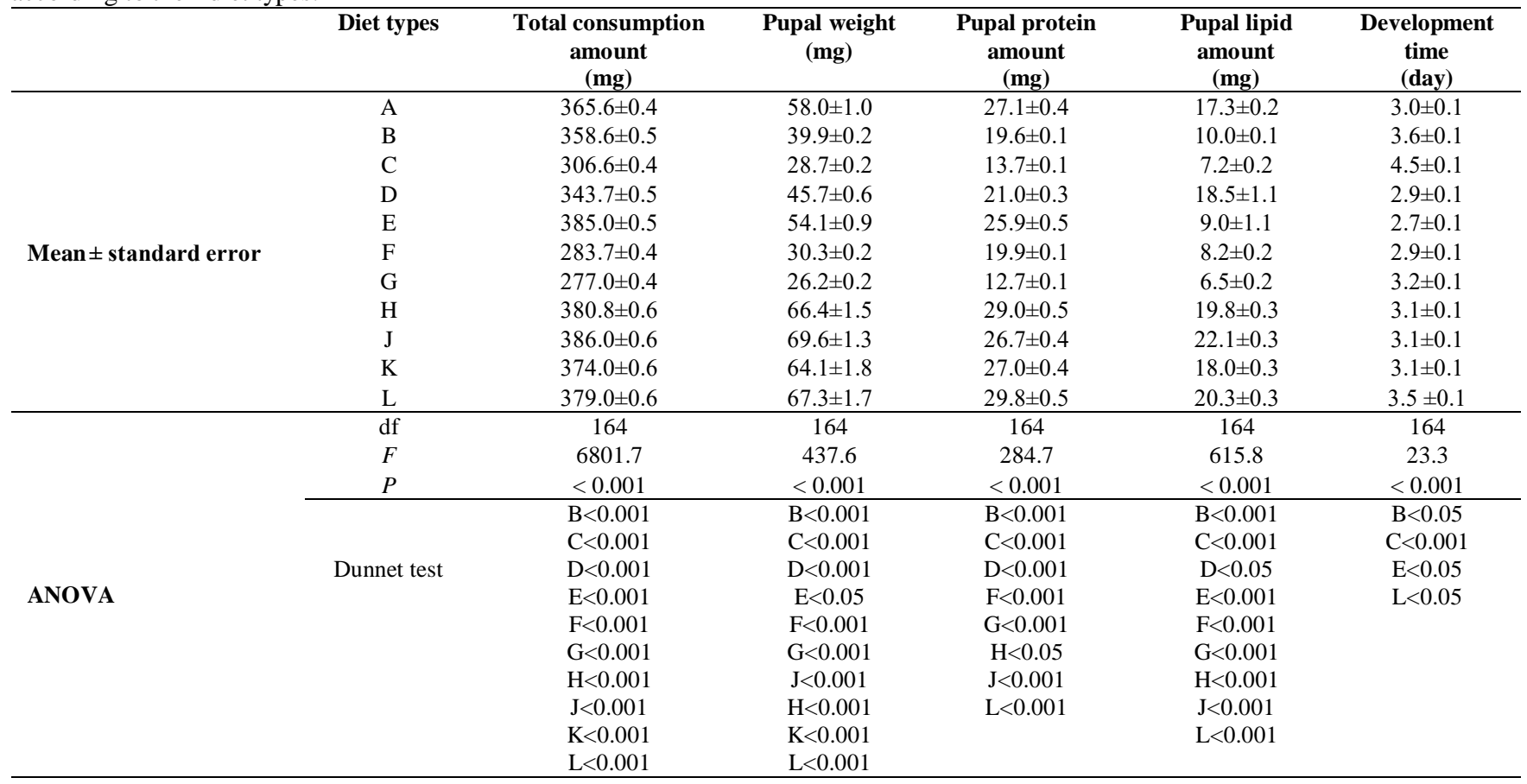

Wu et al., (2014) found that in susceptible strains of Boettcherisca peregrina Robineau-Desvoidy (Diptera: Sarcophagidae), body weight decreased with increasing copper amount. In another study in which Panolis flammea
Denis \& Schiffermüller (Lepidoptera: Noctuidae) and Bupalus piniarius Linnaeus (Lepidoptera: Geometridae) were used (Heliövaara et al., 1989), it was found that pupae whose larval nutrients were closer to the emission source 
were smaller. The decrease in the pupal size of insects affects fecundity (Barah \& Sengupta, 1991). If the fecundity is negatively affected, it means that less number of offspring occurs and; therefore, the population is negatively affected by this situation. We found that all groups containing nickel and cobalt had greater pupal weights than the control group. Also, pupal weight increased with increasing zinc amount in the diet.

Determining the changes in the total protein amount in the whole body or a specific tissue of an insect is essential in determining whether the ingredients in the diet are used effectively by the insect and whether it is effective on the growth of the insect (Büyükgüzel, 2002; Büyükgüzel \& İçen, 2004). While the pupal protein amount decreased with increasing amounts of iron and copper added to the diet, an increase in the amount of protein was observed with increasing amounts of zinc and cobalt. Heavy metals affect protein homeostasis; they can also bind to proteins and inhibit their biological activities (Tamás et al., 2014). In our study, it was determined that the pupal protein amount in the groups containing iron, zinc, and copper was less than control. It indicates that the pupal protein amount is negatively affected by the presence of these metals.

Insects rely on lipid reserves to survive in periods when they are not physiologically fed or to meet the energy requirements of flying, starvation and developing eggs (Patel et al., 2005). Lipid metabolism is necessary for growth and reproduction and provides the energy needed in long-term non-feeding periods (Arrese \& Soulages, 2010). We found that the pupal lipid amount in the groups containing iron and copper was less than the control group. Also, as the amounts of iron, zinc, and copper added to the diet increased, the pupal lipid amounts decreased. In this case, it can be said that these metals may adversely affect vital functions by reducing the pupal lipid amounts. Besides, in our study, it was determined that the lipid amount increased with the increase in nickel and cobalt amounts, and the pupal lipid amounts of these groups were high than control.

Some heavy metals such as $\mathrm{Cu}, \mathrm{Zn}, \mathrm{Fe}, \mathrm{Ni}$, and $\mathrm{Co}$ that we used in our study are essential micronutrients for the development of animals (Yaldız \& Şekeroğlu, 2013). While necessary in trace amounts, they can cause adverse effects at high amounts. For example, we found that with the increase of iron, copper, and cobalt amounts in the diet, the development time of the larvae was prolonged, with the longest development time in the diet group containing the highest amount of iron ( $\mathrm{C}$ diet; Mean=4.5 $\pm 0.1 ; \mathrm{F}=23.3$; $\mathrm{P}<0.001$ ). Prolonged development time may increase the risk of parasitization of larvae (Kaitaniemi \& Ruohomäki, 1999). In this case, it can be said that copper and cobalt, in addition to iron, negatively affect the development time. Also, the development time shortened with increasing zinc amount, the shortest development time in the diet group with the highest zinc amount (E diet; Mean=2.7 $\pm 0.1 ; \mathrm{F}=$ 23.3; $\mathrm{P}<0.05)$.

\section{CONCLUSIONS}

With the development of industrialization and urbanization, heavy metals have become highly toxic environmental pollutants, which seriously impair normal metabolism and the physiological and genetic development of organisms. In our study, it was determined that $H$. cunea was physiologically and developmentally affected by heavy metals in different amounts. The results of this study will shed light on other studies in determining the effects of heavy metal contamination on different insect species.

\section{REFERENCES}

Ali, H., Khan, E. \& Sajad, M.A. (2013). Phytoremediation of heavy metals-concepts and applications. Chemosphere, 91(7), 869-881. DOI: 10.1016/j.chemosphere.2013.01.075

Arora, M., Kiran, B., Rani, S., Rani, A., Kaur, B. \& Mittal, N. (2008). Heavy metal accumulation in vegetables irrigated with water from different sources. Food Chemistry, 111, 811-815. DOI: 10.1016/j.foodchem.2008.04.049

Arrese, E.L. \& Soulages, J.L. (2010). Insect fat body: energy, metabolism, and regulation. Annual Review of Entomology, 55, 207-225. DOI: 10.1146/annurev-ento-112408-085356

Barah, A. \& Sengupta, A.K. (1991). Correlation and regression studies between pupal weight and fecundity of muga silkworm Antheraea assama Westwood (Lepidoptera: Saturniidae) on four different food plants. Acta Physiologica Hungarica, 78(3), 261-264.

Brasso, R.L. \& Cristol, D.A. (2008). Effects of mercury exposure on the reproductive success of tree swallows (Tachycineta bicolor). Ecotoxicology, 17, 133-141. DOI: 10.1007/s10646-007-0163-Z

Büyükgüzel, E. \& Kalender, Y. (2008). Galleria mellonella survivorship, development and protein content in response to dietary antibiotics. Journal of Entomological Science, 43(1), 27-40. DOI: 10.18474/0749-8004-43.1.27

Büyükgüzel, K. (2002). Antimicrobial agents: their combined effects on total protein content of the endoparasitoid Pimpla turionellae L. 
(Hymenoptera: Ichneumonidae). Turkish Journal of Zoology, 26(2), 229-237.

Büyükgüzel, K. \& İçen, E. (2004). Effects of gyrase inhibitors on the total protein content of Pimpla turionellae (Hymenoptera: Ichneumonidae) larvae reared on an artificial diet. Journal of Entomological Science, 39(1), 108-116. DOI: 10.18474/0749-8004-39.1.108

Cempel, M. \& Nikel, G. (2006). Nickel: a review of its sources and environmental toxicology. Polish Journal of Environmental Studies, 15, 375-382.

Dabonne, S., Koffi, B., Kouadio, E., Koffi, A., Due, E. \& Kouame, L. (2010). Traditional utensils: potential sources of poisoning by heavy metals. British Journal of Pharmacology and Toxicology, 1, 90-92.

Freeman, J.L., Stormy Dawn, L., Quinn, C.F., Sirine, F., Marcus, M.A. \& Pilon-Smits, E.A.H. (2007). Selenium accumulation protects plants from herbivory by Orthoptera via toxicity and deterrence. New Phytologist, 175(3), 490-500. DOI: $10.1111 /$ j.1469-8137.2007.02119.x

Gomi, T. (2007). Seasonal adaptations of the fall webworm Hyphantria cunea (Drury) (Lepidoptera: Arctiidae) following its invasion of Japan. Ecological Research, 22(6), 855-861. DOI: 10.1007/s11284-006-0327-y

Gonçalves, M.T., Gonçalves, S.C., Portugal, A., Silva, S., Sousa, J.P. \& Freitas, H. (2007). Effects of nickel hyperaccumulation in Alyssum pintodasilvae on model arthropods representatives of two trophic levels. Plant Soil, 293, 177-188. DOI: 10.1007/s11104-006-9174-4

Göhre, V. \& Paszkowski, U. (2006). Contribution of the arbuscular mycorrhizal symbiosis to heavy metal phytoremediation. Planta, 223, 1115-1122. DOI: 10.1007/s00425-006-0225-0

Görür, G. (2010). Zinc and cadmium accumulation in cabbage aphid (Brevicoryne brassicae) host plants and developmental instability. Insect Science, 16, 65-71. DOI: 10.1111/j.17447917.2009.00255.x

Hejazizadeh, A., Gholamizadeh Ahangar, A. \& Ghorbani, M. (2016). Effect of biochip on lead and cadmium from applied paper factory sewage sludge by sunflower (Heliantus annus L.). Water and Soil Science University of Tabriz, 26(1/2), 259-271.

Heliövaara, K., Väisänen, R. \& Kemppi, E. (1989). Change of pupal size of Panolis flammea (Lepidoptera: Noctuidae) and Bupalus piniarius (Geometridae) in response to concentration of industrial pollutants in their food plant. Oecologia, 79, 179-183. DOI: 10.1007/BF00388475

Kaitaniemi, P. \& Ruohomäki, K. (1999). Effects of autumn temperature and oviposition date on timing of larval development and risk of parasitism in a spring folivore. Oikos, 84, 435442.

Kara, Y. (2005). Bioaccumulation of $\mathrm{Cu}, \mathrm{Zn}$ and $\mathrm{Ni}$ from the wastewater by treated Nasturtium officinale. International Journal of Environmental Science and Technology, 2, 63-67. DOI: 10.1007/BF03325859

Kazemi-Dinan, A., Thomaschky, S., Stein, R.J., Krämer, U. \& Müller, C. (2014). Zinc and cadmium hyperaccumulation act as deterrents towards specialist herbivores and impede the performance of a generalist herbivore. New Phytologist, 202, 628-639. DOI: 10.1111/nph.12663

Oonincx, D.A.G.B., van Broekhoven, S., van Huis, A. \& van Loon, J.J.A. (2015). Feed conversion, survival and development and composition of four insect species on diets composed of food byproducts. Plos One, 10(12), e0144601. DOI: 10.1371/journal.pone.0144601

Patel, R.T., Soulages, J.L., Hariharasundaram, B. \& Arrese, E.L. (2005). Activation of the lipid droplet controls the rate of lipolysis of triglycerides in the insect fat body. The Journal of Biological Chemistry, 280, 22624-22631. DOI: 10.1074/jbc.M413128200

Pedersen, H.C. \& Saether, M. (1999). Effects of cadmium on parental behaviour in free-living willow ptarmigan hens. Ecotoxicology, 8, 1-7. DOI: 10.1023/A:1008836908985

Sánchez-Chardi, A., Ribeiro, C.A.O. \& Nadal, J. (2009). Metals in liver and kidneys and the effects of chronic exposure to pyrite mine pollution in the shrew Crocidura russula inhabiting the protected wetland of Donana. Chemosphere, 76, 387-394. DOI: 10.1016/j.chemosphere.2009.03.036

Scheirs, J., Vandevyvere, I., Wollaert, K., Blust, R. \& Bruyn, L.D. (2006). Plant-mediated effects of heavy metal pollution on host choice of a grass miner. Environmental Pollution, 143, 138-145. DOI: 10.1016/j.envpol.2005.11.001

Sharma, P., Mohan, L., Dua, K.K. \& Srivastava, C.N. (2011). Status of carbohydrate, protein and lipid profile in the mosquito larvae treated with certain phytoextracts. Asian Pacific Journal of Tropical 
Medicine, 4, 301-304. DOI: 10.1016/S1995-

7645(11)60090-4

Simpson, S.J. \& Raubenheimer, D. (2001). The geometric analysis of nutrient allelochemica interactions: a case study using locusts. Ecology, 82, 422-439. DOI: $10.2307 / 2679870$

Tamás, M.J., Sharma, S.K., Ibstedt, S., Jacobson T. \& Christen, P. (2014). Heavy metals and metalloids as a cause for protein misfolding and aggregation. Biomolecules, 4, 252-267. DOI: 10.3390/biom4010252

Vesk, P.A. \& Reichman, S.M. (2009). Hyperaccumulators and herbivores-a bayesian meta-analysis of feeding choice trials. Journal of Chemical Ecology, 35, 289-296. DOI: 10.1007/s10886-009-9607-7

Witeska, M., Sarnowski, P., Lugowska, K. \& Kowal, E. (2014). The effects of cadmium and copper on embryonic and larval development of ide Leuciscus idus L. Fish Physiology and Biochemistry, 40, 151-163. DOI: 10.1007/s10695-013-9832-4

Wu, G., Gao, X., Zhu, J., Hu, C. \& Ye, G. (2014). Copper resistance selection and activity changes of antioxidases in the flesh fly Boettcherisca peregrina. Journal of Insect Science, 14(1), 1161. PMCID: PMC4222311

Yaldız, G. \& Şekeroğlu, N. (2013). Tibbi ve aromatik bitkilerin bazı ağır metallere tepkisi. Türk Bilimsel Derlemeler Dergisi, 6(1), 80-84.

Yamamoto, R.T. (1969). Mass rearing of tobacco hornworm. II. Larval rearing and pupation. Journal of Economic Entomology, 62, 1427-1431. DOI: 10.1093/jee/62.6.1427

Zhang, L.W., Kang, K., Jiang, S.C., Zhang, Y.N., Wang, T.T., Zhang, J., Sun, L., Yang, Y.Q., Huang, C.C., Jiang, L.Y. \& Ding, D.G. (2016). Analysis of the antennal transcriptome and insights into olfactory genes in Hyphantria cunea (Drury). Plos One, 11(10), e0164729. DOI: 10.1371/journal.pone.0164729 